JINOTEP Vol 8 (3) (2021): 289-298

DOI: $10.17977 /$ um031v8i32021p289

JINOTEP (Jurnal Inovasi Teknologi Pembelajaran)

Kajian dan Riset Dalam Teknologi Pembelajaran

http://journal2.um.ac.id/index.php/jinotep/index

\title{
PENGEMBANGAN E-BOOK BERBASIS PROBLEM BASED LEARNING PADA PELAJARAN BAHASA JAWA KELAS IV SEKOLAH DASAR
}

\author{
Liana $^{1}$, Iskandar Wiryokusumo ${ }^{2}$, Ibut Priono Leksono ${ }^{3}$ \\ ${ }^{1}$ Mahasiswa Teknologi Pendidikan, Pascasarjana, Universitas PGRI Adi Buana Surabaya ${ }^{2}{ }^{3}$ Teknologi \\ Pendidikan, Pascasarjana, Universitas PGRI Adi Buana Surabaya
}

\section{Article History}

Received: 01-09-2021

Accepted: 28-10-2021

Published: 01-11-2021

\section{Keywords}

E-Book; Bahasa Jawa; Problem Based Learning

\begin{abstract}
Abstrak
Penelitian ini bertujuan untuk menghasilkan e-book Bahasa Jawa berbasis Problem Based Learning yang sesuai dengan karakteristik siswa kelas IV yang termasuk generasi Z. Generasi berjuluk generasi intenet ini mustahil menjalani kehidupan tanpa teknologi. Kemajuan teknologi akibat revolusi industri yang terus berkembang menghasilkan tantangan masa depan bagi siswa. Berpikir kritis untuk memecahkan masalah adalah salah satu jalan keluar yang perlu dibiasakan. Oleh karena itu dibutuhkan bahan ajar yang sesuai, yaitu e-book berbasis Problem Based Learning. Penelitian ini adalah penelitian Research and Development (R\&D) dengan model pengembangan Dick \& Carey. Hasil validasi dari ahli materi terhadap e-book mencapai 92,36\% (sangat layak). Hasil ahli desain mencapai 91,67\% (sangat layak). Hasil ahli media mencapai 96\% (sangat layak). Hasil review guru mencapai 94,22\% (sangat layak). Hasil uji coba kelompok kecil mencapai 85,21\% (sangat layak) dan hasil uji coba lapangan mencapai 90,51\% (sangat layak). Dari hasil data dan analisis penelitian, disimpulkan bahwa pengembangan e-book Bahasa Jawa berbasis Problem Based Learning bagi generasi $\mathrm{Z}$ yang membiasakan siswa berpikir kritis berkategori sangat layak dan dapat diterapkan guru dalam pembelajaran.
\end{abstract}

\begin{abstract}
This research aims to produce a Javanese e-book based on Problem Based Learning that is suitable for the characteristics of fourth grade students, including $Z$ generation. This generation nicknamed the internet generation is impossible to live without technology. Technological advances due to the industrial revolution that continues to develop produce future challenges for students. Critical thinking to solve problems is one way out that needs to be accustomed. Therefore, appropriate teaching materials are needed, namely e-book based on Problem Based Learning. This research is a Research and Development (R\&D) with Dick \& Carey development model. The validation results from material experts on e-books reached 91.67\% (very feasible). Media expert results reached 96\% (very feasible). The result of the teacher's review reached $94.22 \%$ (very feasible). The results of the small group evaluation reached $85.21 \%$ (very feasible). From the results of data and research analysis, it was concluded that the development of a Javanese e-book based on Problem Based Learning for $Z$ generation which familiarizes students to think critically is categorized as very feasible and can be applied by teachers in learning.
\end{abstract}

Corresponding author: Liana

Address: J1. Dukuh Menanggal XII No.17, Jawa Timur 60234

Instansi: Universitas PGRI Adi Buana Surabaya

E-mail: lianavalent123@gmail.com
2021 Universitas Negeri Malang p-ISSN 2406-8780 e-ISSN 2654-7953 
290 JINOTEP (Jurnal Inovasi dan Teknologi Pembelajaran) Kajian dan Riset dalam Teknologi Pembelajaran Vol.8, No.3, November 2021, Hal. 289-298

\section{PENDAHULUAN}

Seiring berjalannya waktu, generasi terus berkembang dalam beberapa kategori. Beberapa kategori berdasar rentang tahun kelahiran yaitu baby boomers, generasi $\mathrm{X}$ (yang lahir tahun 1961-1980), generasi Y (yang lahir tahun 19901995), dan generasi $Z$ (yang lahir tahun 19952010). Siswa kelas IV Sekolah Dasar termasuk generasi $\mathrm{Z}$ yaitu generasi yang mendapat julukan generasi internet dan paling banyak mendapat sorotan. Generasi $\mathrm{Z}$ adalah generasi yang paling ahli dalam mempergunakan teknologi, cerdas, kreatif, dan kritis akibat keberagaman keahlian yang dimiliki (Christiani \& Ikasari, 2020). Generasi Z lebih menyukai belajar dan menghabiskan banyak waktu melalui teknologi yaitu internet. Smartphone adalah simbol status bagi generasi ini (Csobanka, 2016).

Generasi $\mathrm{Z}$ cenderung lebih menyukai bahasa asing atau Bahasa Indonesia dan mulai melupakan Bahasa Jawa. Dibandingkan dengan bahasa asing seperti Bahasa Inggris, bahasa daerah kurang memberikan keuntungan ekonomis. Banyak lowongan pekerjaan yang membutuhkan pekerja dengan kemampuan berbahasa Inggris. Nyaris, tidak ada lowongan pekerjaan yang membutuhkan pekerja dengan kemampuan berbahasa daerah khususnya Bahasa Jawa. Belum lagi, ditambah dengan banyaknya ragam halus dan aksara tersendiri dalam tata cara penulisannya yang sangat tidak ada penerapannya di dalam kehidupan seharihari. Rendahnya minat siswa terhadap mata pelajaran Bahasa Jawa dikarenakan siswa mengalami kesulitan ketika menulis aksara Jawa. Kebanyakkan siswa menganggap aksara Jawa adalah materi yang sulit karena penulisannya memiliki aturan rumit dan banyak kemiripan bentuk di setiap aksaranya (Silviarista et al., 2018).

Menurut penelitian Mulyani et al., (2013) menunjukkan bahwa proses pembelajaran Bahasa Jawa yang dilaksanakan di Sleman belum berjalan sebagaimana mestinya. Salah satu permasalahan dalam pembelajaran Bahasa Jawa adalah kurangnya sarana dan prasarana termasuk bahan ajar sehingga pengajar sulit menyampaikan pesan kepada para siswa. Selain itu, peserta didik kurang meminati pelajaran Bahasa Jawa karena dianggap kurang menarik (Aribowo, 2018). Peserta didik menjadi cepat jenuh dalam pembelajaran akibat langkanya media pembelajaran, kurangnya minat dan motivasi belajar peserta didik, sarana dan infrastruktur yang kurang memadai, serta kesibukan guru akibat beban administrasi.

Dwi Bambang Putut Setiadi mengatakan bahwa meningkatnya jumlah bahasa daerah yang hampir punah dikarenakan pelajar atau generasi muda kurang menghargai bahasa daerah sebagai bahasa ibu mereka (Mulyana, 2008). Bahasa Jawa adalah salah satu bahasa daerah yang mulai tersisihkan. Penggunaan Bahasa Jawa dalam berkomunikasi sehari-hari dianggap ketinggalan zaman sehingga penggunaan Bahasa Jawa semakin hari semakin berkurang. Sebaliknya, penggunaan Bahasa Indonesia dan bahasa internasional semakin meningkat. Walau Bahasa Jawa telah diajarkan sejak kelas I jenjang Sekolah Dasar sebagai muatan lokal, tetapi Bahasa Jawa tetap dianggap sulit oleh siswa kelas IV sekalipun.

Revolusi industri 4.0 yang diikuti dengan kemunculan era digital sangat memanjakan generasi $\mathrm{Z}$. Generasi $\mathrm{Z}$ tidak dapat hidup tanpa internet karena mereka tergantung dan akrab dengan penggunaan teknologi akibat paparan internet sejak lahir (Goh \& Lee, 2018). Tidak hanya memiliki keuntungan, revolusi industri 4.0 juga memiliki kelemahan. Salah satu kelemahan tersebut adalah otomatisasi yang dapat menyebabkan banyaknya pengangguran. Oleh karena itu, pengembangan sumber daya manusia melalui pembelajaran berstandar diperlukan bagi para siswa (Industri et al., 2018). Penerapan pembelajaran dengan model Problem Based Learning terbukti dapat meningkatkan kemampuan siswa dalam berpikir kritis. Hal tersebut dibuktikan dengan adanya peningkatan kemampuan berpikir kritis siswa secara kontinu. Pembelajaran dengan model Problem Based Learning dapat membuat siswa terlibat langsung dalam pembelajaran di mana guru hanya sebagai pengarah untuk menggali pengetahuan dan interaksi antar siswa (Kristiawan et al., 2018). 
Mengembangkan berpikir kritis untuk memecahkan masalah sangat penting untuk diajarkan kepada para siswa (Nafiah \& Suyanto, 2014). Siswa harus dibiasakan untuk menghadapi permasalahan sehingga menjadi pribadi yang tanggap, kreatif, dan memiliki sikap semangat untuk segera memecahkan masalahnya. Keterampilan memecahkan masalah memiliki arti penting bagi para siswa terutama untuk menghadapi tantangan masa depan.

Metode pembelajaran berbasis masalah (Problem Based Learning) memerlukan keterampilan berpikir siswa secara individu atau kelompok melalui lingkungan nyata untuk menyelesaikan masalah. Penerapan tahapan Problem Based Learning dapat meningkatkan kompetensi siswa yaitu nilai pengetahuan, nilai keterampilan, dan nilai sikap (Purnomo et al. 2019). Tujuan dari Problem Based Learning sejalan dengan kurikulum yang sedang berlaku di Indonesia yaitu Kurikulum 2013. Penerapan kurikulum 2013 diharapkan mampu mewujudkan mutu pendidikan yang lebih baik (Amin, 2013).

Bahan ajar elektronik (e-book) sangat diperlukan mengingat bahan ajar inilah yang sangat cocok bagi generasi $\mathrm{Z}$ yang mendapat julukan generasi internet selain buku teks. Bahan ajar elektronik dapat memasukkan unsur suara dan gambar yang dinamis seperti video (Christianto \& Dwiyogo, 2020). Selain itu, e-book memberikan kesempatan untuk meningkatkan pendalaman materi karena siswa tidak hanya membaca teks. Selain itu, e-book dapat membuat siswa aktif dan mandiri dalam belajar (Muhammad et al., 2015). E-book yang didukung dengan model pembelajaran Problem Based Learning bercirikan masalah dunia nyata dapat membuat siswa berpikir kritis, memiliki keterampilan memecahkan masalah, dan menghasilkan rasa ingin tahu. Problem Based Learning akan merubah pembelajaran konvensional menjadi pola belajar yang lebih aktif. E-book berbasis Problem Based Learning yang dirancang dalam bentuk soft file sehingga dapat dioperasikan menggunakan ponsel, komputer, atau laptop ini dapat memfasilitasi siswa untuk belajar secara mandiri melalui pertanyaan-pertanyaan yang dirancang secara menarik dan bermakna sehingga memotivasi belajar siswa (Astuti et al., 2017).

Dalam penelitian yang dikembangkan oleh Muga et al., (2017) yang berjudul "Pengembangan Bahan Ajar Elektronik Berbasis Model Problem Based Learning Dengan Menggunakan Model Dick and Carey" menghasilkan sebuah e-book yang dikatakan sangat baik. Demikian pula dengan uji yang dikembangkan berdasarkan tanggapan mahasiswa menunjukkan bahwa e-book sangat baik di mana terdapat beberapa aktivitas pemecahan masalah dalam kegiatan diskusi dan contoh-contoh kasus di dalamnya. Sedang dalam penelitian yang dikembangkan oleh Filivani \& Agung (2021) e-book yang dihasilkan memiliki tingkat validitas, hasil uji ahli konten pembelajaran, ahli desain pembelajaran, dan ahli media pembelajaran yang berada pada kriteria sangat layak. Persentase keseluruhan angket pada uji coba kelompok kecil menunjukkan rerata 97,50\% yang berarti $e$-book dalam kriteria sangat layak. Berdasar serangkaian uji coba yang dilaksanakan, kesimpulan yang dapat diambil bahwa e-book yang dikembangkan dengan memuat nilai-nilai karakter layak untuk dijadikan bahan ajar dalam pembelajaran PPKn kelas V Sekolah Dasar. Oleh karena itu, pengembang tertarik untuk melakukan pengembangan serupa hingga uji lapangan dengan mata pelajaran yang berbeda, yaitu Bahasa Jawa. Diharapkan pengembangan e-book ini nantinya layak untuk digunakan.

Pembelajaran Bahasa Jawa yang digunakan kelas IV dalam kurikulum hanya bergantung penuh kepada buku teks dari pemerintah yang kurang menarik minat generasi $\mathrm{Z}$ serta kurang terdapatnya aktivitas pemecahan masalah dalam kegiatan diskusi dan contoh-contoh kasus yang dapat membuat siswa berpikir kritis di mana kompetensi tersebut perlu dikuasai peserta didik untuk menghadapi tantangan masa depan. Sehingga dibutuhkan e-book yang cocok dan menarik bagi generasi $\mathrm{Z}$ serta dapat membantu berpikir kritis siswa. Berangkat dari permasalahan tersebut, maka peneliti tertarik untuk mengembangkan $e$-book berbasis Problem Based Learning yang sesuai dengan karakteristik generasi $\mathrm{Z}$ dan 
292 JINOTEP (Jurnal Inovasi dan Teknologi Pembelajaran) Kajian dan Riset dalam Teknologi Pembelajaran Vol.8, No.3, November 2021, Hal. 289-298

mengembangkan kemampuan berpikir kritis siswa kelas IV Sekolah Dasar.

\section{METODE}

Penelitian ini dikembangkan dengan ini menggunakan model pengembangan dari Dick \& Carey. Langkah prosedural komponen dalam menghasilkan sebuah produk model Dick \& Carey (2005) yaitu: 1) mengidentifikasi tujuan instruksional umum; 2) melakukan analisis pembelajaran; 3) mengidentifikasi perilaku dan karakteristik awal pebelajar; 4) merumuskan tujuan pembelajaran khusus; 5) mengembangkan item-item tes acuan patokan; 6) mengembangkan strategi pembelajaran; 7) mengembangkan dan menulis bahan pembelajaran; 8) mendesain dan melakukan evaluasi formatif; 9) merevisi kegiatan pembelajaran; 10) mendesain dan melaksanakan evaluasi sumatif.

Dalam penelitian ini, peneliti melakukan penyederhanaan dan pembatasan pengembangan model Dick \& Carey (2005) menjadi 8 langkah yang dipaparkan ke dalam lima tahapan yaitu:

1. Tahap I: menentukan bahan ajar yang akan dikembangkan. E-book dipilih karena sesuai dengan gaya generasi $\mathrm{Z}$ yang cenderung berhubungan dengan teknologi dan internet.

2. Tahap II: mengidentifikasi tujuan pembelajaran, melakukan analisis pembelajaran, mengidentifikasi pebelajar dan konteks, menulis tujuan pembelajaran khusus, dan mengembangkan instrumen penilaian.

3. Tahap III: mengembangkan strategi pembelajaran atau yang biasa disebut langkah-langkah pembelajaran meliputi:
a) kegiatan awal;
b) kegiatan inti;
c) kegiatan akhir/penutup (Lenggono, 2019).

4. Tahap IV: penyusunan dan pengembangan e-book dengan komponen utama berupa cover, kata pengantar, daftar isi, cover bab, materi, latihan soal, lembar nasehat, dan daftar pustaka.

5. Mendesain dan melakukan evaluasi formatif dan merevisi produk pengembangan. Tahap ini dilakukan setelah e-book selesai dan mendapat masukan dari para ahli di luar perancang sehingga dapat diperbaiki yaitu ahli isi/materi, ahli desain, ahli media, 3 review guru/teman sejawat, 8 siswa dalam uji kelompok kecil, dan 26 siswa dalam 1 rombongan belajar yaitu kelas IV-B sebagai uji lapangan.

Untuk mengetahui kelayakan produk yang dihasilkan, maka diperlukan analisis hasil validasi. E-book divalidasi oleh ahli isi/materi, ahli media, dan ahli desain. E-Book yang telah divalidasi kemudian direvisi sehingga diperoleh e-book revisi tahap I. E-book revisi ini direview oleh teman sejawat dan diujicobakan kepada kelompok kecil. Langkah berikutnya, e-book diujicobakan secara lapangan. Melalui tahapan tersebut, maka dihasilkan produk akhir.

Data yang dipakai dalam pengembangan e-book ini adalah kuesioner terstruktur berupa angket dengan menggunakan skala likert. Asmara (2015) menyatakan bahwa perlu pengubahan penilaian dari bentuk kualitatif menjadi kuantitatif hasil angket validasi dengan ketentuan a) sangat baik $(\mathrm{SB})=5$, b) baik $(B)=4, \mathrm{c})$ cukup $(\mathrm{C})=3$, d) kurang $(\mathrm{K})=2$, dan d) sangat kurang $(\mathrm{SK})=1$.

Penelitian ini menggunakan teknik analisis deskriptif. Hasil angket diolah dengan bentuk deskriptif. Rumus yang digunakan untuk menghitung skor rata-rata digunakan rumus dari Ernawati (2017):

$$
\bar{X}=\frac{\sum x}{n} \ldots \ldots(1)
$$

Keterangan:

$\bar{X}=$ skor rata-rata

$\mathrm{N}=$ jumlah penilai

$\sum \mathrm{x}=$ skor total masing-masing

Tabel 1. Kriteria Penilaian Kelayakan E-Book

\begin{tabular}{cll}
\hline $\begin{array}{c}\text { Tingkat } \\
\text { Pencapaian }\end{array}$ & Kualifikasi & Keterangan \\
\hline $81 \%-100 \%$ & Sangat layak & $\begin{array}{l}\text { Tidak perlu } \\
\text { direvisi }\end{array}$ \\
$61 \%-80 \%$ & Layak & $\begin{array}{l}\text { Tidak perlu } \\
\text { direvisi }\end{array}$ \\
$41 \%-60 \%$ & Cukup layak & Direvisi \\
$21 \%-40 \%$ & Kurang layak & Direvisi \\
$0 \%-20 \%$ & $\begin{array}{l}\text { Sangat kurang } \\
\text { layak }\end{array}$ & Direvisi \\
\hline
\end{tabular}


Selanjutnya, untuk menghitung persentase keseluruhan subyek menurut Ernawati (2017) digunakan rumus:

$$
\text { Hasil }=\frac{\text { total skor } \text { yang diperoleh }}{\text { skor maksimum }} \times 100 \%
$$

Tingkat validasi dan penilaian berdasarkan angket digunakan kriteria kelayakan pada tabel 1. (Riduwan, 2011). Penilaian e-book berbasis Problem Based Learning dalam penelitian dan pengembangan ini ditentukan dengan minimal "Layak".

\section{HASIL}

Pengembangan E-Book berbasis Problem Based Learning pada pelajaran Bahasa Jawa divalidasi oleh ahli isi atau materi, ahli desain, ahli media, dan teman sejawat untuk menilai e-book yang telah dikembangkan serta memberi saran sehingga peneliti dapat melakukan perbaikan.

\section{Tabel 2. Hasil Validasi Ahli Isi/Materi}

\begin{tabular}{clcccc}
\hline No & Aspek Penilaian & $\begin{array}{c}\text { Rerata/ Skor } \\
\text { Maksimal }\end{array}$ & $\begin{array}{c}\mathbf{P} \\
(\%)\end{array}$ & Kualifikasi & $\begin{array}{c}\text { Keputusan } \\
\text { Uji }\end{array}$ \\
\hline 1. & Kelayak an isi & $90 / 100$ & $90 \%$ & $\begin{array}{c}\text { Sanga } \\
\text { layak } \\
\text { Sangat layak }\end{array}$ & Tidak perlu revisi \\
2. & $\begin{array}{l}\text { Kelayak an penya } \\
\text { jian }\end{array}$ & $68 / 70$ & $97 \%$ & Tidak perlu revisi \\
3. & $\begin{array}{l}\text { Penilaian bahasa } \\
\text { Penilaian pendekat }\end{array}$ & $56 / 65$ & $86 \%$ & Sangat layak & Tidak perlu revisi \\
& an & $35 / 35$ & $100 \%$ & Sangat layak & Tidak perlu revisi \\
\hline
\end{tabular}

Tabel 3. Hasil Validasi Ahli Desain

\begin{tabular}{clcccc}
\hline No & Aspek Penilaian & $\begin{array}{c}\text { Rerata/ Skor } \\
\text { Maksimal }\end{array}$ & $\begin{array}{c}\mathbf{P} \\
(\%)\end{array}$ & Kuali fikasi & $\begin{array}{c}\text { Keputusan } \\
\text { Uji }\end{array}$ \\
\hline 1. & Desain sampul & $13 / 15$ & $87 \%$ & Sangat layak & Tidak perlu revisi \\
2. & Desain isi & $24 / 25$ & $96 \%$ & Sagat layak & Tidak perlu revisi \\
3. & Kejelasan & $18 / 20$ & $90 \%$ & Sangat layak & Tidak perlu revisi \\
\hline
\end{tabular}

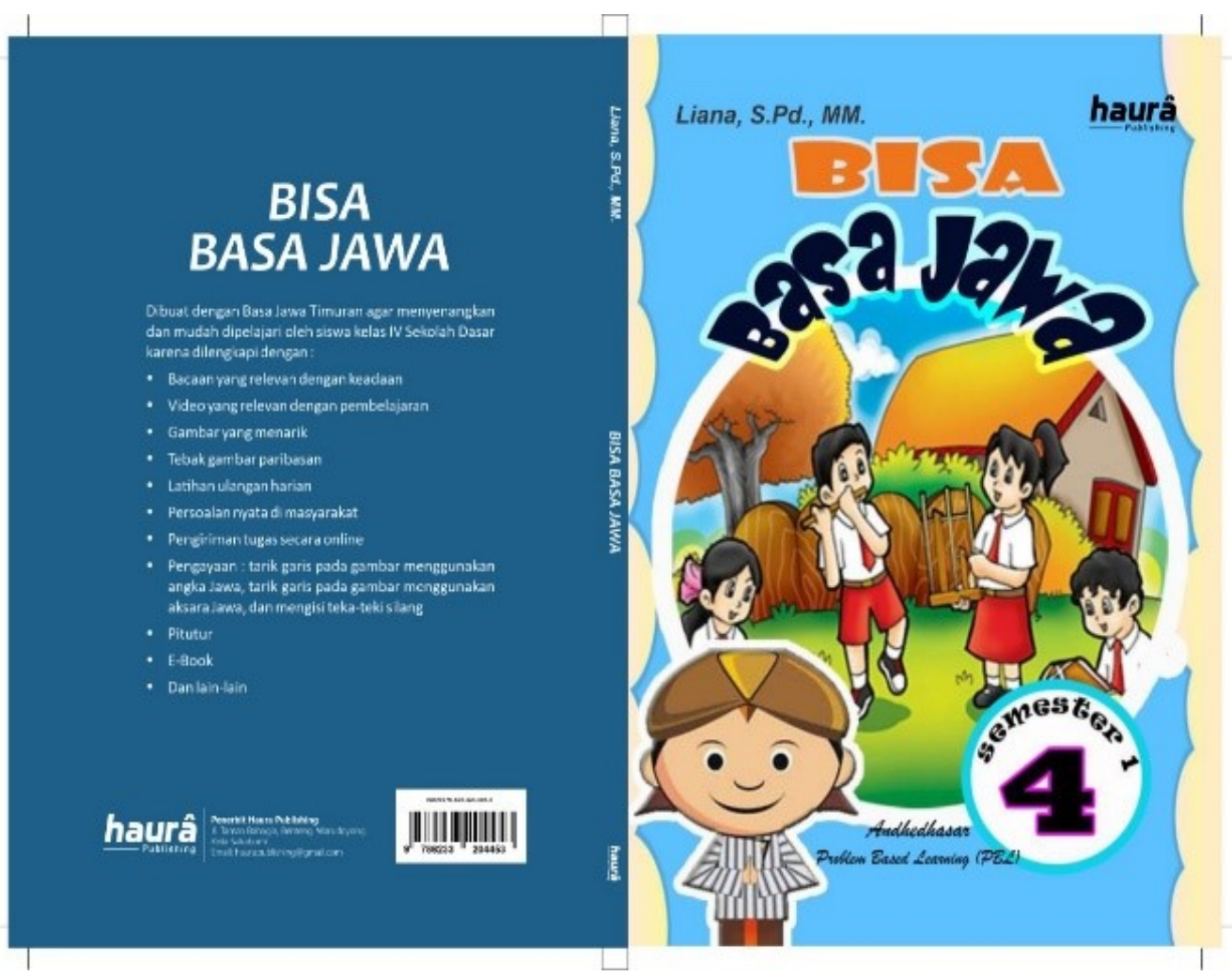

Gambar 1. E-Book Bahasa Jawa kelas IV (dapat diakses pada https://drive.google.com/drive/folders/108F7cGseBbsNrFAFFmwaATU3jHETcI-H? usp=sharing) 
294 JINOTEP (Jurnal Inovasi dan Teknologi Pembelajaran) Kajian dan Riset dalam Teknologi Pembelajaran Vol.8, No.3, November 2021, Hal. 289-298

Validasi Ahli Isi/Materi

Isi materi e-book ini divalidasi oleh Dosen Pendidikan Bahasa Jawa Universitas Negeri Surabaya (UNESA). Validasi dilakukan pada aspek kelayakan isi, kelayakan penyajian, penilaian bahasa, dan penilaian pendekatan Pendidikan Bahasa Jawa berbasis Problem Based Learning. Berikut ini hasil validasi dari ahli isi atau materi.

Hasil validasi dari ahli isi/materi menunjukkan kelayakan isi mencapai 90\% dengan kualifikasi sangat layak. Kelayakan penyajian memperoleh nilai persentase 97\% dengan kualifikasi sangat layak, penilaian bahasa memperoleh nilai persentase $86 \%$ dengan kualifikasi sangat layak, penilaian pendekatan Pendidikan Bahasa Jawa Problem Based Learning memperoleh nilai persentase $100 \%$ dengan kualifikasi sangat layak. Secara keseluruhan persentase rerata total mencapai $92 \%$.

\section{Validasi Ahli Desain}

Pada tahap ini, validasi dilakukan oleh seorang Dosen dari Teknologi Pendidikan Pasca Sarjana UNIPA Adi Buana Surabaya. Validasi desain dilakukan dengan memberi penilaian pada aspek desain sampul bahan ajar, desain isi, dan kejelasan.

Hasil validasi menunjukkan aspek desain sampul bahan ajar mencapai $87 \%$ dengan kualifikasi sangat layak. Aspek desain isi memperoleh nilai persentase $96 \%$ dengan kualifikasi sangat layak, dan aspek kejelasan memperoleh nilai persentase $90 \%$ dengan kualifikasi sangat layak. Hasil analisis penilaian yang dilakukan oleh ahli desain mencapai rerata $91,67 \%$.

\section{Validasi Ahli Media}

Validasi ahli media dilakukan oleh Dosen Teknologi Pendidikan Pasca Sarjana UNIPA Adi Buana Surabaya. Validasi media dilakukan dengan memberikan penilaian pada aspek sajian materi, isi materi media, ilustrasi gambar, dan penggunaan media.

Hasil validasi di atas, menunjukkan aspek sajian materi mencapai $90 \%$ dengan kualifikasi sangat layak. Aspek isi materi media memperoleh persentase $96 \%$ dengan kualifikasi sangat layak. Aspek ilustrasi gambar memperoleh persentase $100 \%$ dengan kualifikasi sangat layak, dan aspek penggunaan

\begin{tabular}{|c|c|c|c|c|c|}
\hline \multicolumn{6}{|c|}{ Tabel 4. Hasil Validasi Ahli Media } \\
\hline No & $\begin{array}{c}\text { Aspek } \\
\text { Penilaian }\end{array}$ & $\begin{array}{c}\text { Rerata/ } \\
\text { Skor } \\
\text { Maksimal }\end{array}$ & $\begin{array}{c}\mathbf{P} \\
(\%)\end{array}$ & $\begin{array}{c}\text { Kuali } \\
\text {-fikasi }\end{array}$ & $\begin{array}{c}\text { Keputusan } \\
\text { Uji }\end{array}$ \\
\hline 1. & $\begin{array}{l}\text { Sajian } \\
\text { materi }\end{array}$ & $18 / 20$ & $90 \%$ & $\begin{array}{c}\text { Sangat } \\
\text { layak }\end{array}$ & $\begin{array}{l}\text { Tidak perlu } \\
\text { revisi }\end{array}$ \\
\hline 2. & $\begin{array}{l}\text { Isi materi } \\
\text { media }\end{array}$ & $24 / 25$ & $96 \%$ & $\begin{array}{c}\text { Sangat } \\
\text { layak }\end{array}$ & $\begin{array}{l}\text { Tidak perlu } \\
\text { revisi }\end{array}$ \\
\hline 3. & $\begin{array}{l}\text { Ilustrasi } \\
\text { gambar }\end{array}$ & $20 / 20$ & $100 \%$ & $\begin{array}{c}\text { Sangat } \\
\text { layak }\end{array}$ & $\begin{array}{l}\text { Tidak perlu } \\
\text { revisi }\end{array}$ \\
\hline 4. & $\begin{array}{l}\text { Pengguna } \\
\text { an media }\end{array}$ & $10 / 10$ & $100 \%$ & $\begin{array}{c}\text { Sangat } \\
\text { layak }\end{array}$ & $\begin{array}{l}\text { Tidak perlu } \\
\text { revisi }\end{array}$ \\
\hline
\end{tabular}

media mencapai $100 \%$ dengan kualifikasi sangat layak. Rerata total hasil analisis penilaian ahli media mencapai $96 \%$.

\section{UJI COBA PRODUK \\ Review Guru/Teman Sejawat}

Uji coba produk diperoleh dari review teman sejawat sebanyak 3 (tiga) guru Bahasa Jawa di Surabaya untuk menilai sejauh mana e-book layak dan menarik untuk digunakan siswa.

Berdasar review dari teman sejawat, dilihat dari aspek format $e$-book, isi $e$-book, kesesuaian e-book, bahasa, tulisan, dan tampilan e-book diperoleh jumlah persentase keseluruhan yaitu 94,22\% yang dapat dilihat pada Gambar 2 . Guru/teman sejawat pada gambar diberi keterangan PR 1 (Peer Review 1), PR 2 (Peer Review 2), dan PR 3 (Peer Review 3).

\section{Uji Coba Kelompok Kecil}

Hasil uji coba kelompok kecil yang diperoleh dari 8 siswa kelas IV SDKr. Anak Panah dapat dilihat pada Gambar 3. Siswa yang mengikuti uji coba kelompok kecil pada gambar diberi keterangan P1-P8 (Pengguna 1Pengguna 8).

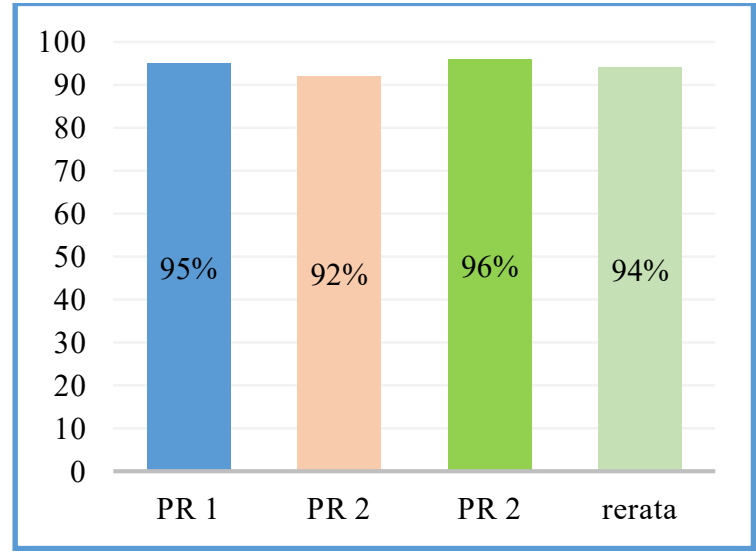

Gambar 2.Hasil Review Teman Sejawat 


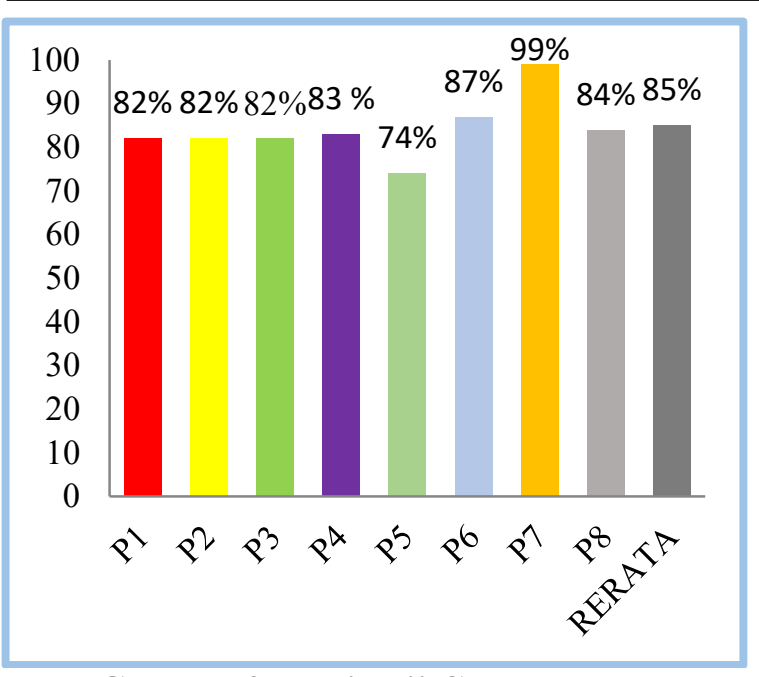

Gambar 3. Hasil Uji Coba Kelompok Kecil

Berdasarkan hasil yang diperoleh, jumlah persentase keseluruhan dari hasil uji coba kelompok kecil menunjukkan angka rerata $85,21 \%$. Hasil angket dari uji coba kelompok ini dikorelasikan dengan tabel kriteria kelayakan produk, e-book yang telah diujicobakan pada kelompok kecil berkategori sangat layak dan tidak perlu direvisi.

\section{Uji Coba Lapangan}

Kegiatan uji coba lapangan dilakukan kepada siswa kelas IV-B SDKr. Anak Panah pada awal Bulan September 2021. Kegiatan pembelajaran dilakukan oleh guru Bahasa Jawa SDKr. Anak Panah Surabaya.

Siswa kelas IV-B merupakan satu rombongan belajar yang terdiri dari 8 siswa laki-laki dan 18 siswa perempuan. Hasil uji coba lapangan tampak pada Gambar 4.

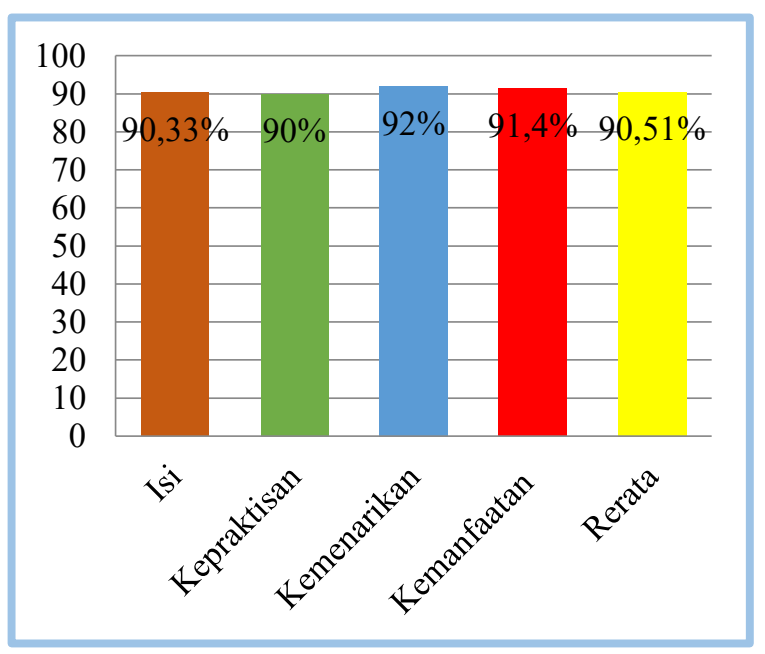

Gambar 4. Hasil Uji Coba Lapangan
Tampak hasil dari aspek isi sebesar 90,33\% dengan kualifikasi sangat layak. Aspek kepraktisan memperoleh persentase 90\% dengan kualifikasi sangat layak. Aspek kemenarikan memperoleh persentasetase 91\% dengan kualifikasi sangat layak. Aspek kemanfaatan memperoleh persentasetase 91,40\% dengan kualifikasi sangat layak. Rerata total hasil uji coba lapangan yaitu $90,51 \%$.

\section{PEMBAHASAN}

Berdasar hasil analisis data dari validasi ahli isi atau materi, persentase rerata total secara keseluruhan mencapai 92,36\%. Jika dikorelasikan dengan aspek kelayakan produk pada tabel 1, e-book yang dikembangkan memiliki kualifikasi sangat layak dan tidak perlu direvisi. Validator memberikan komentar dan saran antara lain: Pertama, beberapa penggunaan kata perlu disesuaikan dengan kaidah penulisan Bahasa Jawa. Contoh: penulisan "Suroboyo" seharusnya "Surabaya", "kaliyan" seharusnya "sampeyan" dan seterusnya. Kedua, guru harus mampu menarik motivasi belajar siswa khususnya siswa yang bukan merupakan suku Jawa untuk mencintai Bahasa Jawa. Tantangan yang serupa juga dialami Hanafri et al., (2015) dalam penelitiannya, di mana harus mengajarkan Bahasa Jawa bagi sekolah di wilayah Tangerang yang kebanyakkan adalah suku Sunda yang rata-rata menggunakan Bahasa Sunda. Oleh karena itu diperlukan aplikasi mobile yang membantu dan mempermudah siswa untuk belajar Bahasa Jawa. Selain itu, Putri et al. (2014) dalam penelitiannya menyatakan bahwa guru harus jeli dalam memperhatikan ejaan dan substansi bahan ajar pelajaran Bahasa Jawa.

Hasil validasi oleh ahli desain secara keseluruhan mencapai 91,67\%. Jika dikorelasikan dengan aspek kelayakan produk pada tabel 1, e-book yang dikembangkan memiliki kualifikasi sangat layak dan tidak perlu direvisi. Validator memberikan komentar dan saran agar mengupayakan penggunaan huruf yang beragam agar dapat meningkatkan minat baca siswa. Hal tersebut sejalan dengan hasil penelitian dari Ramadan (2011) yang 
296 JINOTEP (Jurnal Inovasi dan Teknologi Pembelajaran) Kajian dan Riset dalam Teknologi Pembelajaran Vol.8, No.3, November 2021, Hal. 289-298

menyatakan bahwa gaya huruf dapat meningkatkan kecepatan membaca teks yang pada akhirnya dapat mengarah pada pengalaman membaca online yang lebih optimal.

Hasil validasi oleh ahli media secara keseluruhan mencapai 96\%. Jika dikorelasikan dengan aspek kelayakan produk pada tabel 1 , e-book yang dikembangkan mencapai kualifikasi sangat layak dan tidak perlu direvisi. Validator memberikan komentar dan saran agar mengupayakan pencerahan warna background pada e-book sehingga menarik minat belajar siswa. Hal ini sejalan dengan hasil penelitian dari (Ramadan, 2011) yang menyatakan bahwa warna background yang kontras pada e-book dapat membuat waktu reaksi membaca siswa yang lebih cepat.

Hasil review teman sejawat secara keseluruhan mencapai 94,22\%. Jika dikorelasikan dengan aspek kelayakan produk pada tabel 1, e-book yang dikembangkan mencapai kualifikasi sangat layak dan tidak perlu direvisi. Beberapa masukan dari teman sejawat adalah judul per bab diberi animasi seperti contoh pada gladhen-gladhen sehingga ada pembeda di tiap babnya. Hal ini sejalan dengan hasil penelitian dari (Al-Qassabi \& AlSamarraie, 2013) yang menyatakan bahwa audio, video, dan animasi yang terintegrasi membuat e-book lebih menarik, mendukung, dan pembelajaran yang kondusif.

Hasil uji coba produk pengembangan e-book ini pada kelompok kecil memiliki persentase total mencapai $85,21 \%$. Jika dikorelasikan dengan aspek kelayakan produk pada tabel 1, e-book yang dikembangkan mencapai kualifikasi sangat layak dan tidak perlu direvisi. Beberapa masukan dari uji coba kelompok kecil ini adalah: a) e-book yang dikembangkan bagus dan menarik; b) e-book memiliki gambar dan video yang dapat membantu memahami pelajaran Bahasa Jawa; c) e-book mudah dipahami dan dapat membantu pelajaran Bahasa Jawa; d) ilustrasi gambar di e-book perlu diperbanyak. Hal ini sejalan dengan hasil penelitian dari Filivani \& Agung (2021) yang menyatakan bahwa video pembelajaran menjadikan pembelajaran menarik bagi siswa karena tidak hanya menggunakan buku dari sekolah. Selain itu, e-book interaktif juga dapat meningkatkan kemampuan berpikir kritis siswa karena menggunakan audio, animasi, dan video dibanding dengan media konvensional (Fry, 2019).

Hasil uji coba lapangan menunjukkan nilai persentase aspek isi mencapai $90,33 \%$. Hal ini menunjukkan kelayakan materi e-book, sejauh mana kejelasan tujuan dengan materi, bahan ajar yang sesuai dengan kehidupan nyata sehari-hari, kemudahan memahami materi serta pengerjaan soal dalam e-book, adanya pemfasilitasan untuk bekerja sama antar teman, serta kecocokan gambar dan video terhadap materi e-book. Pada aspek kepraktisan diperoleh nilai persentasetase mencapai $90 \%$. Hal ini menunjukkan kemudahan penggunaan atau pengoperasian e-book secara mandiri oleh siswa, video, dan latihan yang mudah diakses, serta penggunaan teknologi yang up to date karena materi dapat diakses menggunakan ponsel berupa flipping e-book. Pada aspek kemenarikan diperoleh nilai persentase mencapai 91\%. Hal ini menunjukkan bahwa gambar, video, dan warna $e$-book dapat menarik minat belajar siswa. Sedang pada aspek kemanfaatan diperoleh nilai persentase 91,4\%. Hal ini menunjukkan bahwa e-book memberikan manfaat bagi siswa yaitu menarik minat untuk belajar Bahasa Jawa dan membantu berpikir kritis karena penyajian permasalahan nyata di sekitar siswa yang dimasukkan sebagai materi. Rerata total dari hasil uji coba lapangan mencapai persentase 90,51. Jika dikorelasikan dengan aspek kelayakan produk pada tabel 1 , pengembangan e-book Bahasa Jawa berbasis Problem Based Learning bagi generasi $\mathrm{Z}$ yang membiasakan siswa berpikir kritis berkategori sangat layak, tidak perlu direvisi, dan dapat diterapkan guru dalam pembelajaran. Hal yang sama dikemukakan dalam penelitian Salubi et al. (2018) yang menyatakan bahwa generasi Z lebih sering mengakses e-book dan e-jurnal di perpustakaan dengan menggunakan wifi. Morgan (2013) menyatakan dalam penelitiannya bahwa e-book dapat memotivasi 
siswa dalam belajar. Selain itu, penggunaan teknologi secara positif seperti bahan ajar elektronik (e-book) akan memberikan dampak yang sangat besar dalam dunia pendidikan. Hal itu akan membuat materi pembelajaran lebih menarik sehingga siswa menjadi aktif dan mampu memahami pembelajaran (Tanjung, 2019).

\section{SIMPULAN}

Dari hasil analisis data dapat diambil sebuah penjelasan bahwa e-book berbasis Problem Based Learning pada pelajaran Bahasa Jawa yang dikembangkan telah sesuai dengan gaya generasi $\mathrm{Z}$ yang dikenal sebagai generasi internet. Para siswa tertarik dan terbiasa berpikir kritis karena e-book berisi aktivitas pemecahan masalah dalam kegiatan diskusi dan contoh-contoh kasus permasalahan nyata di sekitar mereka.

E-book berbasis Problem Based Learning tersebut dinyatakan sangat layak untuk digunakan sebagai bahan ajar Bahasa Jawa di kelas IV Sekolah Dasar. Hal ini dibuktikan dengan adanya hasil perhitungan statistik yaitu dari ahli isi/media didapatkan skor persentase $92,36 \%$, ahli desain sebesar 91,67\%, dan ahli media yang mencapai persentase $96 \%$. Hasil review guru atau teman sejawat sebagai penilai e-book mencapai 94,22\%, hasil uji coba kelompok kecil mencapai $85,21 \%$, dan skor persentase dari uji lapangan didapat 90,51\%.

Pengembangan e-book berbasis Problem Based Learning pada pelajaran Bahasa Jawa kelas IV Sekolah Dasar ini dapat dijadikan referensi untuk dapat digunakan dalam proses pembelajaran selain buku teks di sekolah lain dengan penyesuaian-penyesuaian tertentu terutama jika akan dipakai di luar Jawa Timur. Demi kesempurnaan pengembangan $e$-book ini diperlukan penelitian lebih lanjut sesuai kebutuhan.

\section{DAFTAR RUJUKAN}

Al-Qassabi, H., \& Al-Samarraie, H. (2013). Applying Gagne's Nine Events in the Design of an Interactive eBook to Learn 3D Animation. Advances in Computing, 2013(3), 60-72. https://doi.org/10.5923/j.ac.20130303.05

Amin, S. (2013). Tinjauan keunggulan dan kelemahan penerapan kurikulum 2013. AlBidayah, Vol. 5(Issue 2), 261-279.

Aribowo, E. K. (2018). Digitalisasi Aksara Jawa Dan Pemanfaatannya Sebagai Media Pembelajaran Bagi Musyawarah Guru Mata Pelajaran Bahasa Jawa Smp Kabupaten Klaten. Warta LPM, 21(2), 59-70. https://doi.org/10.23917/warta.v21i2.5620

Asmara, A. P. (2015). Pengembangan Media PemAyu, N. rafika, Arthur, R., \& Neolaka, A. (2019). Pengembangan Media Pembelajaran Berbasis Komik Pada Konstruksi Bangunan 1. Jurnal PenSil, 8(1), 40-46. https://doi.org/10.21009/jpensil.v8i1.10628bela jaran Berbasis Audio Visual Tenta. Jurnal Ilmiah Didaktika, 15(2), 156-178.

Astuti, D., Siswandari, P., \& Santosa, D. (2017). EBook for Problem Based Learning to Improve Learning Outcome of the Students. 158(Ictte), 220-227. 17.2017 .45

Christiani, L. C., \& Ikasari, P. N. (2020). Generasi Z dan Pemeliharaan Relasi Antar Generasi dalam Perspektif Budaya Jawa. Jurnal Komunikasi Dan Kajian Media, 4(2), 84-105.

Christianto, J., \& Dwiyogo, W. D. (2020). Pengembangan Media Pembelajaran Cricket Berbasis Mobile Learning Pada Tim Olahraga Cricket Universitas Negeri Malang. Gelanggang Pendidikan Jasmani Indonesia, $3(2)$, 168-174. https://doi.org/10.17977/um040v3i2p168-174

Csobanka, Z. E. (2016). The Z Generation. Acta Technologica Dubnicae, 6(2), 63-76. https://doi.org/10.1515/atd-2016-0012

Dick, W and L. Carey, J. O. Carey. 2005. The systematic Design of Instruction. New York: Logman.

Ernawati, I. (2017). Uji Kelayakan Media Pembelajaran Interaktif Pada Mata Pelajaran Administrasi Server. Elinvo (Electronics, Informatics, and Vocational Education), 2(2), 204-210. https://doi.org/10.21831/elinvo.v2i2.17315

Filivani, P. N., \& Agung, A. A. G. (2021). Developing E-Book Contained Character Values in PPKn Lesson Content Grade V Elementary School. Journal of Education Technology, 5(1), https://doi.org/10.23887/jet.v5i1.32047

Fry, A. (2019). Ebook rate of use in OhioLINK: A ten-year study of local and consortial use of publisher packages in Ohio. College and Research Libraries, 80(6), 827-842. https://doi.org/10.5860/crl.80.6.827

Goh, E., \& Lee, C. (2018). A workforce to be reckoned with: The emerging pivotal Generation Z hospitality workforce. International Journal of Hospitality Management, 73(October 2017), 20-28. 
298 JINOTEP (Jurnal Inovasi dan Teknologi Pembelajaran) Kajian dan Riset dalam Teknologi Pembelajaran Vol.8, No.3, November 2021, Hal. 289-298

https://doi.org/10.1016/j.ijhm.2018.01.016

Hanafri, M. I., Budiman, A., \& Akbar, N. A. (2015). Game Edukasi Tebak Gambar Bahasa Jawa Menggunakan Adobe Flash CS6 Berbasis Android. Jurnal Sisfotek Global, 5(2), 50-53.

Industri, R., Tantangan, D. A. N., \& Sosial, P. (2018). Revolusi Industri 4.0 Dan Tantangan Perubahan Sosial. IPTEK Journal of Proceedings Series, $0(5), \quad 22-27$. https://doi.org/10.12962/j23546026.y2018i5.44 17

Kristiawan, I., Toenlioe, A., \& Sulthoni, S. (2018). Penerapan Pembelajaran Problem Solving Pada Mata Pelajaran Pendidikan Kewarganegaraan Untuk Meningkatkan Keterampilan Berfikir Dan Aktivitas Belajar Siswa. JINOTEP (Jurnal Inovasi Dan Teknologi Pembelajaran) Kajian Dan Riset Dalam Teknologi Pembelajaran, 3(1), 62-71. https://doi.org/10.17977/um031v3i12016p062

Lenggono, W. (2019). Peran Media ICT Pada Pembelajaran Al Islam dan Kemuhammadiyahan dan Penggunaanya di SMP Muhammadiyah 1 Purwokerto A . Introduction / Pendahuluan Perkembangan teknologi semakin pesat dan berkembang seiring kehidupan manusia yang semakin komplek (Elyas , 2. 18(1), 157-178.

Morgan, H. (2013). Multimodal Children's E-Books Help Young Learners in Reading. Early Childhood Education Journal, 41(6), 477-483. https://doi.org/10.1007/s10643-013-0575-8

Muga, W., Suryono, B., \& Januarisca, E. L. (2017). Pengembangan Bahan Ajar Elektronik Berbasis Model Problem Based Learning Dengan Menggunakan Model Dick and Carey. Journal of Education Technology, 1(4), 260. https://doi.org/10.23887/jet.v1i4.12863

Muhammad, M., Rahadian, D., \& Safitri, E. R. (2015). Penggunaan Digital Book Berbasis Android Untuk Pada Pelajaran Bahasa Arab. PEDAGOGIA : Jurnal Ilmu Pendidikan, 170182.

Mulyana. (2008). Pembelajaran Bahasa dan Sastra Daerah Dalam Kerangka Budaya. Jogjakarta: Tiara Wacana.

Mulyani, S., Harti W, S., \& Hendri, Z. (2013). Development of Learning Content Model Based on Regional Potentials To Endorse the Learning. Jurnal Kependidikan, 43(1), 51-60.
Nafiah, Y. N., \& Suyanto, W. (2014). Penerapan model problem-based learning untuk meningkatkan keterampilan berpikir kritis dan hasil belajar siswa. In Jurnal Pendidikan Vokasi (Vol. 4, Issue 1). https://doi.org/10.21831/jpv.v4i1.2540

Purnomo, H., Santosa, B., \& Tentama, F. (2019). Implementation of Problem-Based Learning and Group Investigation ( $\mathrm{Pbl}$ Go-in) To Improve Vocational Students' Competence. Journal of Vocational Education Studies, 2(1), 47. https://doi.org/10.12928/joves.v2i1.750

Putri, W. A., Irianto, S., \& Wiarsih, C. (2014). The Local Content Analysis of Javanese Material for Fifth Graders of Elementary School. 6(2), $162-178$.

http://jurnalnasional.ump.ac.id/index.php/Dina mika/article/view/907\%0Ahttps://lens.org/132450-165-370-865

Ramadan, M. Z. (2011). Evaluating college students' performance of Arabic typeface style, font size, page layout and foreground/background color combinations of e-book materials. In Journal of King Saud University - Engineering Sciences (Vol. 23, Issue 2, pp. 89-100). https://doi.org/10.1016/j.jksues.2011.03.005

Riduwan, 2011. Metode dan Teknik Menyusun Proposal Penelitian. Bandung: Alfabeta.

Salubi, O. G., Ondari-Okemwa, E., \& Nekhwevha, F. (2018). Utilisation of library information resources among generation $\mathrm{Z}$ students: Facts and fiction. Publications, 6(2), 1-12. https://doi.org/10.3390/publications6020016

Silviarista, M., Setyosari, P., \& Sihkabuden, S. (2018). Pengembangan Multimedia Pembelajaran Berbasis Mobile Untuk Mata Pelajaran Bahasa Jawa Materi Aksara Jawa Kelas VIII SMP. JINOTEP (Jurnal Inovasi Dan Teknologi Pembelajaran) Kajian Dan Riset Dalam Teknologi Pembelajaran, 4(1), 22-27.

https://doi.org/10.17977/um031v4i12017p022

Tanjung, R. F. (2019). Answering the Challenge of Industrial Revolution 4.0 Through Improved Skills Use of Technology College. International Journal for Educational and Vocational Studies, $1(1), \quad 11$. https://doi.org/10.29103/ijevs.v1i1.1374 